\title{
Breast cancer risk assessment using genetic variants and risk factors in a Singapore Chinese population
}

\author{
Charmaine Pei Ling Lee ${ }^{1,2 \dagger}$, Astrid Irwanto ${ }^{2,3 \dagger}$, Agus Salim ${ }^{4}$ Jian-min Yuan ${ }^{5}$, Jianjun Liü ${ }^{2,3}$, Woon Puay Koh ${ }^{6,2}$ \\ and Mikael Hartman $2,7,8^{*}$
}

\begin{abstract}
Introduction: Genetic variants for breast cancer risk identified in genome-wide association studies (GWAS) in Western populations require further testing in Asian populations. A risk assessment model incorporating both validated genetic variants and established risk factors may improve its performance in risk prediction of Asian women.

Methods: A nested case-control study of female breast cancer (411 cases and 1,212 controls) within the Singapore Chinese Health Study was conducted to investigate the effects of 51 genetic variants identified in previous GWAS on breast cancer risk. The independent effect of these genetic variants was assessed by creating a summed genetic risk score (GRS) after adjustment for body mass index and the Gail model risk factors for breast cancer.

Results: The GRS was an independent predictor of breast cancer risk in Chinese women. The multivariate-adjusted odds ratios (95\% confidence intervals) of breast cancer for the second, third, and fourth quartiles of the GRS were 1.26 (0.90 to 1.76 ), 1.47 (1.06 to 2.04 ) and 1.75 (1.27 to 2.41 ) respectively ( $P$ for trend $<0.001$ ). In addition to established risk factors, the GRS improved the classification of $6.2 \%$ of women for their absolute risk of breast cancer in the next five years.
\end{abstract}

Conclusions: Genetic variants on top of conventional risk factors can improve the risk prediction of breast cancer in Chinese women.

\section{Introduction}

Breast cancer is a heterogeneous disease that is associated with genetic and environmental factors. Prior to genetic studies, investigations have mainly revolved around the presence of a family history, hormonal and reproductiverelated risk factors [1-3] with the effects of other lifestyle factors being queried recently. To date, the risk of disease has been shown to increase with a woman's age, age at menopause, age at first live birth, previous occurrence of atypical hyperplasia and family history [4]. The inherited predisposition to this malignancy has also been thoroughly studied to reveal two major susceptibility genes, BRCA1

\footnotetext{
* Correspondence: mikael_hartman@nuhs.edu.sg

${ }^{\dagger}$ Equal contributors

${ }^{2}$ Saw Swee Hock School of Public Health, National University of Singapore,

21 Lower Kent Ridge Road, Singapore 119077, Singapore

${ }^{7}$ Department of Surgery, National University Hospital, 5 Lower Kent Ridge

Road, Singapore 119074, Singapore

Full list of author information is available at the end of the article
}

and BRCA2 [5,6], as well as other gene mutations of lower penetrance [7-12]. However, these account for less than $5 \%$ of breast cancer cases, suggesting a more widespread relevance of common genetic variants in the population when considered cumulatively [13-17]. In addition, migrant and twin studies have hinted of an environmental component that can possibly overwrite the genetic influences on breast cancer, suggesting a multi-factorial nature of breast cancer risk or gene-environment interactions $[18,19]$.

In an attempt to increase the clinical utility of these findings [20], statistical models have been designed and validated to aid in personalized risk assessment. Notably, the Gail model is the most widely used for breast cancer risk prediction. However, the model does not consider genetic factors directly [1] and has limited discriminatory power [21]. On the contrary, other studies in general have until recently ignored hormonal and reproductive characteristics of individual women $[22,23]$. Unfortunately, most

\section{Biomed Central}


of the models are still lacking in their predictive ability [24-27] and may be inapplicable to Chinese populations.

Despite having a much lower breast cancer incidence in Asia than in Europe [28], a rapidly increasing trend toward rates in the West is a cause for concern [29]. Singapore women are reported to have one of the highest rates of breast cancer incidence in the region with an annual increase of more than 3\% [30]. As the linkage disequilibrium patterns differ among ethnic groups [31], findings from genome-wide association studies (GWAS) done on Caucasian populations [7,32-36] are potentially less relevant to Asian women [31,37-39]. In this nested case-control study, we incorporated a set of established GWAS risk alleles into a model with well-known lifestyle factors and evaluated its impact on predicting breast cancer risk in a Singapore Chinese cohort.

\section{Methods}

\section{Study subjects}

The subjects included in this study are women enrolled in the Singapore Chinese Health Study (SCHS), a populationbased cohort study which has been described in detail previously [40]. Briefly, the cohort comprises 63,257 Chinese men and women between the ages of 45 to 74 who were recruited from 1993 to 1998. Participants were Singapore citizens or permanent residents who lived in governmentbuilt housing estates, and belonged to either of two major dialect groups: Hokkien or Cantonese. All participants were interviewed at baseline in their homes where they provided information on demographics, diet, level of physical activity, occupational exposure, smoking, and medical history. The women were also asked about their menstrual and reproductive history.

Between April 1994 and December 1999, blood and single-void urine specimens were collected from a random $3 \%$ sample of study enrollees. Details of the biospecimen collection, processing and storage procedures have been described previously [41]. Between January 2000 and April 2005, we extended our biospecimen collection to all surviving cohort members and collected biospecimens from 32,575 participants, representing a consent rate of about $60 \%$ of surviving cohort participants at that time.

Informed consent was obtained from all participants at baseline interview, as well as at time of biospecimen collection. The Institutional Review Board at the National University of Singapore has approved this study.

\section{Case ascertainment}

Incident breast cancer cases were identified through the population-based cancer registry in Singapore. As of 28 June 2010, 941 had developed breast cancer in this cohort and among them, 414 donated blood previously and were included in this study. Compared with breast cancer patients who did not donate a blood sample, those who donated were younger at diagnosis (54.9 versus 56.0 years). Patients who did not donate blood samples were less educated (39.1\% had no formal education) than those who did (25.1\% had no formal education). There was also a higher proportion of family history of breast cancer among those who donated blood $(\mathrm{n}=11,2.66 \%)$ compared to those who did not donate $(n=4,0.76 \%)$.

\section{Control selection}

For each of the 414 breast cancer cases, up to three control subjects were randomly selected among all female cohort participants who had donated blood samples, and who were alive and free of breast cancer history at the time of cancer diagnosis of their index case. The chosen controls were matched to the index case on age at study enrollment ( \pm 3 years), dialect group (Hokkien, Cantonese), menopausal status at sample collection, dates of study enrollment ( \pm 2 years) and of blood collection ( \pm 6 months). For the 414 cases, there were six cases where only two eligible controls were found for each of them, and 408 cases where three controls were found for each of them.

\section{SNP selection, genotyping and quality control}

We reviewed all published GWAS results related to breast cancer [42]. Single nucleotide polymorphisms (SNPs) from various studies [43-45], including more than 40 novel SNPs that were very recently identified from the Breast Cancer Association Consortium (BCAC) [46] and subsequently evaluated in a collaborative study on East Asian women [39], were evaluated for their application in breast cancer risk assessment. Due to differences in haplotype structure between Caucasian and Chinese populations, among SNPs in the same loci and having linkage disequilibrium $\left(\mathrm{LD}, \mathrm{r}^{2}\right)$ of more than 0.8 in HapMap Han Chinese in Beijing (CHB) population [47], the SNP with the greatest statistically significant association with breast cancer was genotyped, to ensure that all SNPs analyzed for risk prediction were independent of each other. SNPs with minor allele frequencies (MAF) less than 5\% according to the Singapore Genome Variation Project (SGVP) [48] were also excluded.

Genotyping was done using the Sequenom iPLEX Gold MassARRAY system in 96-well plates (Sequenom, San Diego, CA, USA). MassARRAY Assay Design software was used to design amplification and extension primers (Sequenom). Multiplex PCR amplification was performed using Qiagen HotStart Taq DNA polymerase with $10 \mathrm{ng}$ of genomic DNA (Qiagen, Germantown, MD, USA). Finally, primer extension reactions were carried out according to manufacturer's guidelines. The investigators were blinded to the case/control status of the samples.

Of the initial 69 SNPs, seven SNPs (rs3803662, rs4808801, rs8100241, rs11199914, rs11814448, rs10069690 and rs1292011) could not be analyzed further as they produced poor, indistinguishable clusters, which could result in 
unreliable genotype callings. The average call rate for all SNPs was 98\%, however the minor allele frequencies of rs11571833, rs132390, rs1045485, rs614367, rs999737 and rs8170 fell below the 1\% threshold and were removed from analysis due to low power to detect any association with breast cancer. Deviation from Hardy-Weinberg equilibrium $(P<0.0007)$ in controls was exhibited in the genotype distribution of rs7716600 and these SNPs were also discarded. Among the samples, three cases and fifteen controls did not meet the minimum call rate of $90 \%$. The entire matched set was removed from analyses in the former. Therefore, 55 GWAS SNPs and 1,623 subjects (411 cases and 1,212 controls) were used for further data analyses.

\section{Data analysis}

The SCHS questionnaire contained demographic data, reproductive risk factors, as well as information on diet and lifestyle. Risk factors to be included in the prediction model were selected according to results reported from other studies done on the SCHS cohort and factors used in the original Gail model [1]. Variables in the model were: level of education (no formal schooling, primary school, or secondary school or above), age at first live birth ( $<20,20$ to 24,25 to 29 or nulliparous, $\geq 30$ years), age at menarche $(\geq 14,12$ to $13,<12$ years), history of past breast biopsy (yes, no), family history (yes, no), body mass index (BMI) (<20, 20 to $23.9,24$ to $\left.27.9, \geq 28 \mathrm{~kg} / \mathrm{m}^{2}\right)$ and genetic risk score (GRS) in quartiles based on the controls. BMI was calculated as the weight divided by the squared height $\left(\mathrm{kg} / \mathrm{m}^{2}\right)$. Family history was limited to first-degree relatives only. The history of past breast biopsy (yes/no) was known for 218 (13.2\%) women in the current nested case-control sample. For the remaining women with unknown history of breast biopsy, we imputed the value of history of breast biopsy variable by generating five values and picking the most frequent one, with BMI, estrogen and family history as predictors.

The association between breast cancer and demographic, reproductive, and other baseline characteristics was investigated using the Student's $t$ test and Mantel-Haenszel chi-squared test (linear by linear association) for continuous and categorical variables respectively. Established risk factors namely, parity, age at first live birth, age at menarche, age at menopause, BMI, family history, history of past breast biopsy and estrogen use were examined for their independent associations with breast cancer risk. A GRS was derived for each individual to represent the cumulative effect of the genetic variants on a woman's risk of breast cancer. The Cochran's Q test [49], which is the weighted sum of the squared difference between individual and pooled effects across studies, was used to test for heterogeneity among the current and published studies. The $P$ values were obtained by comparing the statistic with a chi-square distribution with k-1 degrees of freedom, where $\mathrm{k}$ is the number of studies. SNPs were included in the computation of GRS only if heterogeneity was not statistically significant. If not, they were removed on the basis of inconsistency among studies (rs11780156, rs6504950, rs6001930, and rs2981579). To account for multiple hypothesis testing, a false discovery rate (FDR) correction according to the Benjamini-Hochberg procedure [50] was applied. A total of 51 SNPs was included in the computation of GRS. All SNP selection criteria had been decided a priori.

A fixed-effects meta-analysis of published GWAS and our study's findings was performed in order to obtain reliable estimates for each SNP's effect size in the form of a pooled odds ratio ( $\mathrm{pOR}$ ) derived from published and local studies. We weighted the effect size estimates of each study using the inverse of the corresponding standard errors of the respective studies. The GRS for an individual woman is equivalent to the sum of (log pOR of SNP) $\times$ (number of risk alleles that the individual carries for SNP) across all 51 SNPs. The GRS was normalized by dividing it by the average effect size of all SNPs in the population, as outlined previously [51]. Box plots were used to investigate the correlation between GRS and various breast cancer risk factors: age at first live birth, age at menarche, family history, past breast biopsy, BMI and education. Conditional logistic regression was used to calculate the crude and adjusted ORs with a 95\% confidence interval for each risk factor. The $P$ value for trend across categories was reported.

Variables in the Gail model and BMI were used to construct the conditional logistic regression model. The models with and without a GRS were compared in terms of their ability to accurately assess a woman's five-year absolute risk. The probability that an individual $i$ would be free of breast cancer beyond a certain time point, $\mathrm{P}_{\mathrm{i}}$ $(t)$, was calculated as $1-\left(S_{t}\right)^{C i}$, where $S_{t}$ is the proportion of people who were not diagnosed with breast cancer (survived) up to time point $t$. We estimated $S_{t}$ using a Kaplan-Meier survival curve, based on data from the SCHS cohort - the cohort that this nested case-control study is from. Since a five-year risk is required in this study, $t=5$ years. The individual-level coefficient, $C_{i}$ is determined by the formula $\exp \left[\Sigma \beta_{j}\left(x_{i j}-\mu_{j}\right)\right]$, where $\beta_{j}$ is the log odds ratio $(\mathrm{OR})$ of the risk conferred by a variable $\mathrm{j}$, and $\mathrm{x}_{\mathrm{ij}}$ refers to the value of variable $j$ for individual. The average for the variable in the population, $\mu_{\mathrm{j}}$, was approximated using the average among controls. The benefit of adding genetic markers into the predictive model was assessed using a net reclassification improvement (NRI) index [52] that compares the risk classifications under models with and without GRS, to adjust the NRI index for overfitting, the index was further corrected using a bootstrap procedure [53].

As there is general expectation of a more reliable risk prediction model as additional risk variants become 
identified [27,54-56], we tested this hypothesis by rebuilding the model with six, nine, eleven, sixteen and fifty-one (this study) SNPs. These SNPs were chosen in an order in which their association with breast cancer risk was established through time [26,27,57-60].

Conditional logistic regression for the association between SNPs and breast cancer risk, NRI calculation and histogram plots were performed using $\mathrm{R}$ version 2.13.0. All other statistical analyses were performed using IBM SPSS version 21.0 (IBM Corp., Armonk, NY, USA). Statistical tests were two-sided and $P<0.05$ was considered statistically significant. In the test for heterogeneity, $P<0.007$ was used after accounting for multiple testing through Bonferroni correction.

\section{Results}

In total, 411 cases and 1,212 controls were used in the analyses. The distribution of subjects by background characteristics is shown in Table 1. As the cases and controls were matched on age and menopausal status, they were comparable in these aspects. Cases tend to be more well-educated $(P=0.003)$, older at first live birth $(P=0.022)$, report a younger age at menarche $(P=0.033)$, tend to be current estrogen users $(P=0.042)$ and fall under a higher GRS quartile $(P<0.001)$ compared to controls. They also have higher BMI $(P=0.066)$ and a positive family history of breast cancer $(P=0.063)$. The remaining factors comprising sleep and dietary patterns did not differ significantly between the two groups. Figure 1 displays no statistically significant correlation between GRS and the various breast cancer risk factors.

The ORs of the 51 SNPs from the current study and their pooled estimates with previous GWAS studies are displayed in Table 2. The SNPs that tag the ESR1 loci rs2046210 and rs3757318, presented ORs that were statistically significant at the 5\% level. Associations with FOXQ1 $(P=0.088)$ and TOX3 $(P=0.098)$ displayed marginal significance. Apart from two tag SNPs for ESR1, another six SNPs (rs11552449, rs13387042, rs10759243, rs3903072, rs12422552, rs2236007) were also significantly associated with breast cancer in our study. Table S1 in Additional file 1 shows the corresponding pooled estimates when only published studies were used.

The associations between breast cancer risk, established risk factors and GRS were evaluated. Compared to the lowest quartile, women in the highest GRS quartile were close to $80 \%(\mathrm{OR}=1.75,95 \%$ confidence interval $(\mathrm{CI})=1.27$ to 2.41$)$ more likely to have breast cancer (Table 3). The magnitude of the association with GRS and the dose-response relationship remained almost unchanged even after adjusting for the established risk factors and education. Age at first live birth and age at menarche presented statistically significant trends with breast cancer risk, but were no longer significant after adjustment. On the contrary, the association of BMI with risk became significant after other factors were considered. After accounting for GRS and the abovementioned risk factors, neither a positive family history nor a previous breast biopsy was significantly associated with breast cancer risk.

A NRI index was used to assess the improvement in risk classification that would result from adding GRS to a model comprising established risk factors only. Table 4 shows the distribution of women across the various five-year absolute risk categories from $<1.0 \%$ to $\geq 2.5 \%$. Approximately 1,400 women reported five-year cumulative risks of less than $1.5 \%$, while only $5.4 \%$ of cases and $2.0 \%$ of controls were assigned into high-risk groups of $2 \%$ or more. Among the 44 cases who were categorized as having a five-year absolute risk of $1.5 \%$ to $<2.0 \%$ under the model without GRS, 12 of them were shifted to higher risk groups while 13 were moved to the lower risk category of $1.0 \%$ to $<1.5 \%$ when GRS was added to the model. Similarly, for about $46.1 \%$ of the controls who were initially estimated to have $1.5 \%$ to $<2.0 \%$ risk based on established risk factors only, the new model with GRS indicated a lower risk of $1.0 \%$ to $<1.5 \%$, while shifting 12 individuals to the $2.0 \%$ to $<2.5 \%$ risk stratum. The reclassification improvement among cases was $11.2 \%(P<0.001)$, while that for controls was $2.2 \%(P=0.04)$, though the latter was not statistically significant. This led to an NRI of $13.4 \%(P=$ 0.006 ), which decreased to $6.2 \%$ after correcting for optimism using a bootstrap method. This meant, that overall, $6 \%$ of women were reclassified into more appropriate risk groups when a genetic component was considered.

Figure 2 demonstrates the change in model discriminatory power as GRS that represented the cumulative effect of six, nine, eleven, sixteen and fifty-one (this study) SNPs were used in predicting the five-year absolute risk. A marginal improvement in model performance was noted.

\section{Discussion}

We have evaluated a total of 51 SNPs and constructed a GRS to reflect their cumulative effect on breast cancer risk. The genetic score was independently associated with breast cancer risk after adjusting for education and other established risk factors. These common genetic markers, when considered in aggregate, together with reproductive factors and BMI, can improve the risk stratification for close to $10 \%$ of Singapore Chinese women. Similar to past SCHS studies $[61,62]$, cases tend to be more highly educated compared to the controls, hence the adjustment for education in the conditional logistic regression model. However, BMI and family history did not differ significantly between the two groups although the direction of the associations was in agreement with prior knowledge. Failure to reach statistical significance is very likely due to the sample size, hence limiting our study's 
Table 1 Distribution of demographic and established risk factors for breast cancer in cancer patients (cases) and control subjects, The Singapore Chinese Health Study, 1993 to 1998

\begin{tabular}{|c|c|c|c|}
\hline & $\begin{array}{l}\text { Cases } \\
(n=411)\end{array}$ & $\begin{array}{l}\text { Controls } \\
(n=1,212)\end{array}$ & $P^{*}$ \\
\hline \multicolumn{4}{|l|}{ Demographic factors } \\
\hline Mean age, years (SD) & $54.9(7.6)$ & $54.9(7.5)$ & 0.964 \\
\hline Education level, n (\%) & & & 0.003 \\
\hline None & $104(25.3)$ & $399(32.9)$ & \\
\hline Primary & $186(45.3)$ & $518(42.7)$ & \\
\hline Secondary or higher & $121(29.4)$ & $295(24.3)$ & \\
\hline \multicolumn{4}{|l|}{ Reproductive risk factors } \\
\hline Number of live births, n (\%) & & & $<0.001$ \\
\hline Nulliparous & $56(13.6)$ & $85(7.0)$ & \\
\hline $1-2$ & $146(35.5)$ & $369(30.4)$ & \\
\hline $3-4$ & $131(31.9)$ & $483(39.9)$ & \\
\hline 5 or more & $78(19.0)$ & $275(22.7)$ & \\
\hline Mean age at first live birth, years (SD) & $25.6(4.9)$ & $25.0(4.7)$ & 0.022 \\
\hline Mean age at menarche, years (SD) & $14.1(1.7)$ & $14.3(1.8)$ & 0.033 \\
\hline Mean age at menopause, years (SD) & $49.7(4.4)$ & $49.2(4.3)$ & 0.141 \\
\hline Estrogen use, n (\%) & & & 0.042 \\
\hline Non-user & $372(90.5)$ & $1,131(93.3)$ & \\
\hline Ex-user & $8(1.9)$ & $22(1.8)$ & \\
\hline Current user & $31(7.5)$ & $59(4.9)$ & \\
\hline \multicolumn{4}{|l|}{ Other risk factors } \\
\hline Family history of breast cancer, n (\%) & & & 0.063 \\
\hline No & $400(97.3)$ & $1,196(98.7)$ & \\
\hline Yes & $11(2.7)$ & $16(1.3)$ & \\
\hline History of past biopsy, n (\%) & & & 0.252 \\
\hline No & $401(97.6)$ & $1,193(98.4)$ & \\
\hline Yes & $10(2.4)$ & $19(1.6)$ & \\
\hline Mean body mass index, $\mathrm{kg} / \mathrm{m}^{2}(\mathrm{SD})$ & $23.5(3.4)$ & $23.2(3.2)$ & 0.066 \\
\hline Marine n-3 omega fatty acids, g (SD) & $0.90(0.4)$ & $0.90(0.5)$ & 0.299 \\
\hline Vegetable-fruit-soy intake, n (\%) & & & 0.969 \\
\hline 0 & $79(19.2)$ & $241(19.9)$ & \\
\hline 1 & $99(24.1)$ & $307(25.3)$ & \\
\hline 2 & $130(31.6)$ & $332(27.4)$ & \\
\hline 3 & $103(25.1)$ & $332(27.4)$ & \\
\hline Green tea intake in tertiles, n (\%) & & & 0.418 \\
\hline None & $234(56.9)$ & $713(58.8)$ & \\
\hline First & $77(18.7)$ & $219(18.1)$ & \\
\hline Second & $43(10.5)$ & $134(11.1)$ & \\
\hline Third & $57(13.9)$ & $146(12.0)$ & \\
\hline Mean isoflavanoids, mg (SD) & $19.4(20.4)$ & $19.8(17.3)$ & 0.700 \\
\hline Sleep duration, hours per day (SD) & $7.0(1.1)$ & $7.0(1.1)$ & 0.685 \\
\hline
\end{tabular}

Table 1 Distribution of demographic and established risk factors for breast cancer in cancer patients (cases) and control subjects, The Singapore Chinese Health Study, 1993 to 1998 (Continued)

\begin{tabular}{llll}
\hline First $(32.4-43.6)$ & $80(19.5)$ & $326(26.9)$ & $<0.001$ \\
Second $(43.6-47.1)$ & $96(23.4)$ & $310(25.6)$ & \\
Third $(47.1-50.6)$ & $109(26.5)$ & $296(24.4)$ & \\
Fourth $(50.6-65.8)$ & $126(30.7)$ & $280(23.1)$ &
\end{tabular}

*Two-sided $P$ values were derived from chi-squared test for categorical variables and $t$ test for continuous variables; the Mantel-Haenszel chi-squared test for trend with one degree of freedom for categorical variables with more than two levels. SD, standard deviation.

power to detect an association. An attenuated effect of family history $(\mathrm{OR}=1.78)$ after accounting for GRS was noted too. This could be due to the fact that risk variants, which are directly or indirectly incorporated into the GRS are also traits that tend to be inherited together.

To our knowledge, we have investigated the largest number of SNPs for use in risk assessment in an Asian population. Studies by Dai et al., Sueta et al., and Zheng et al. have reported the discriminatory power of using five, seven and eight SNPs respectively $[37,54,55]$. All groups demonstrated the clinical utility that can potentially be achieved with the incorporation of common genetic variants to a model containing established risk factors. Locally, a group has reported the potential effect of combining eight SNPs with clinicopathological factors in risk prediction for a Singapore Chinese population [56]. Likewise, we have shown that common genetic markers, when considered in aggregate, together with reproductive factors and BMI, can improve the risk stratification for close to $10 \%$ of Singapore Chinese women. However, the majority of the cases $(79.6 \%)$ presented low five-year cumulative risks of less than $1.5 \%$ after GRS was considered, with only $5.4 \%$ being assigned five-year cumulative risks of $2 \%$ or more. This suggests that other genetic, physiological and environmental factors not accounted for in this study, which includes novel factors yet to be identified, still account for a large proportion of risk for breast cancer in this population.

To gauge how much value a genetic component can add to an individual's risk assessment, we included the GRS into a model consisting of Gail variables and compared its performance with the model without GRS. Many of the studies published thus far have reported the accuracy of their models in terms of area-under-the-curve (AUC) values [63]. However, AUC is insensitive even when strong predictors are added to the model [64], hence could partially account for insignificant increases in model discrimination. It also does not provide information about the actual risks predicted, therefore, its direct clinical relevance is limited [65]. Instead, we have quantified the degree of correct risk reclassification by calculating the NRI 

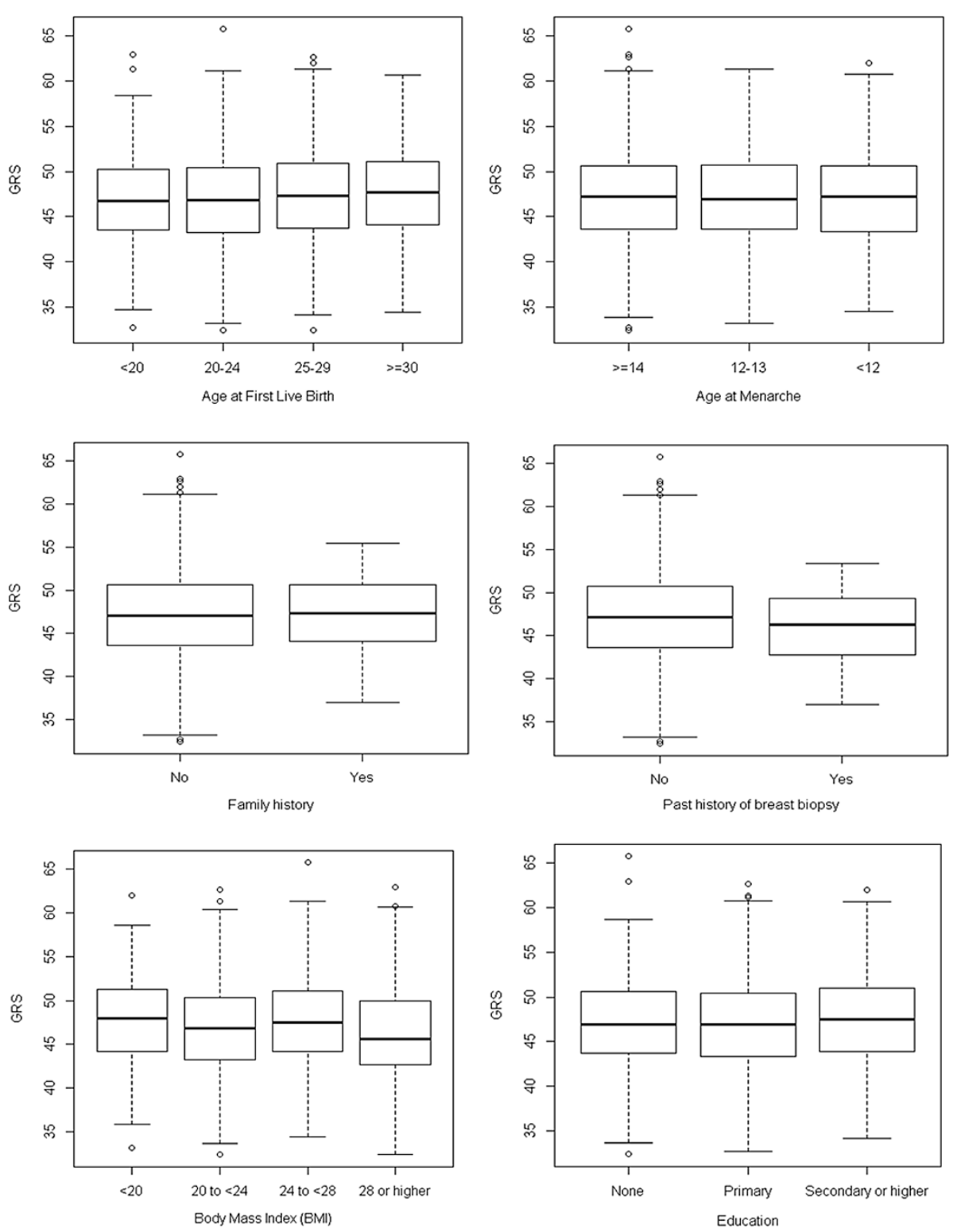

Figure 1 Correlation of genetic risk score (GRS) with various breast cancer risk factors. No statistically significant correlation was observed between GRS and the following breast cancer risk factors: age at first live birth, age at menarche, family history, past history of breast biopsy, body mass index (BMI) and education.

index [52]. Even though NRI depends on arbitrary cutoff points, it is robust to moderate changes [66]. Bootstrapping was performed to account for overfitting of our data to the model, which could in turn lead to an overestimation of model performance. Although we attempted to incorporate all variables of the Gail model in our study, the low uptake of screening mammography meant that we did not have breast biopsy information for a majority of our participants. This problem of 'missing data' was overcome by imputing breast biopsy status based on BMI, estrogen use and family history - variables that differed between those who ever and never had a breast biopsy.
SNPs that tagged the ESR1 gene, which codes for estrogen receptor alpha (ESR $\alpha)$, presented statistically significant associations and consistent ORs in our study. This is in concordance with findings from other groups, which showed substantial effect sizes for SNPs in this region, highlighting a likely association with breast cancer among Chinese and Japanese women [67]. The study conducted among Singaporean Chinese also reported that rs2046210 recorded the largest magnitude, similar to our current study [56]. This is in agreement with a comparison study by Hein et al., which found significant association of the 6q25.1 locus in both Asians and Europeans but greater 
Table 2 The rare allele frequencies of 51 single nucleotide polymorphisms (SNPs) in breast cancer patients and control subjects and their association with risk of breast cancer, The Singapore Chinese Health Study, 1993 to 1998

\begin{tabular}{|c|c|c|c|c|c|c|c|c|c|c|}
\hline Chr & Genes in or near region & SNP & $\begin{array}{l}\text { Effect } \\
\text { allele }\end{array}$ & $\begin{array}{l}\text { RAF in } \\
\text { controls }\end{array}$ & $\begin{array}{l}\text { RAF in } \\
\text { cases }\end{array}$ & $\begin{array}{l}\text { Per-allele } \\
\text { OR }(95 \% \mathrm{Cl})\end{array}$ & SE & $P$ value ${ }^{*}$ & $\begin{array}{l}\text { Pooled } \\
\text { OR }\end{array}$ & $\begin{array}{l}\text { FDR-corrected } \\
P_{\text {het }}\end{array}$ \\
\hline 1 & PEX14 & rs616488 & G & 0.348 & 0.361 & $1.06(0.89,1.26)$ & 0.09 & 0.510 & 0.94 & 0.790 \\
\hline 1 & PTPN22/BCL2L15/AP4B1/DCLRE1B/HIPK1 & rs11552449 & A & 0.596 & 0.556 & $0.85(0.72,0.99)$ & 0.08 & 0.040 & 1.06 & 0.068 \\
\hline 1 & FCGR1B & rs11249433 & G & 0.029 & 0.026 & $0.85(0.52,1.39)$ & 0.25 & 0.517 & 1.09 & 0.371 \\
\hline 2 & INHBB- & rs4849887 & A & 0.259 & 0.269 & $1.05(0.87,1.25)$ & 0.09 & 0.634 & 0.92 & 0.561 \\
\hline 2 & METAP1D/DLX1/DLX2 & rs2016394 & A & 0.195 & 0.191 & $0.96(0.79,1.18)$ & 0.10 & 0.727 & 0.95 & 0.790 \\
\hline 2 & $\mathrm{TNP}^{*}$ & rs13387042 & G & 0.907 & 0.883 & $0.77(0.60,0.99)$ & 0.13 & 0.045 & 0.93 & 0.062 \\
\hline 2 & DIRC3 & rs16857609 & C & 0.376 & 0.367 & $1.07(0.90,1.27)$ & 0.09 & 0.462 & 1.08 & 0.977 \\
\hline 3 & ITPR1/EGOT & rs6762644 & G & 0.098 & 0.096 & $0.97(0.73,1.29)$ & 0.14 & 0.841 & 1.07 & 0.790 \\
\hline 3 & SLC4A7 & rs4973768 & A & 0.190 & 0.186 & $0.97(0.80,1.18)$ & 0.10 & 0.757 & 1.11 & 0.473 \\
\hline 3 & TGFBR2 & rs12493607 & G & 0.278 & 0.262 & $0.91(0.76,1.09)$ & 0.09 & 0.290 & 1.06 & 0.619 \\
\hline 4 & TET2 & rs9790517 & A & 0.613 & 0.635 & $1.09(0.93,1.29)$ & 0.08 & 0.293 & 1.05 & 0.440 \\
\hline 4 & ADAM29 & rs6828523 & A & 0.275 & 0.271 & $0.99(0.82,1.18)$ & 0.09 & 0.879 & 0.90 & 0.729 \\
\hline 5 & $5 p 12$ (intergenic) & rs4415084 & $C$ & 0.441 & 0.434 & $0.96(0.82,1.14)$ & 0.08 & 0.668 & 1.15 & 0.087 \\
\hline 5 & MRPS30 & rs10941679 & G & 0.499 & 0.519 & $1.09(0.93,1.29)$ & 0.08 & 0.289 & 1.12 & 0.409 \\
\hline 5 & MAP3K1 ${ }^{\ddagger}$ & rs889312 & C & 0.589 & 0.577 & $0.96(0.82,1.14)$ & 0.08 & 0.666 & 1.05 & 0.727 \\
\hline 5 & RAB3C & rs10472076 & G & 0.247 & 0.260 & $1.07(0.89,1.28)$ & 0.09 & 0.465 & 1.04 & 0.500 \\
\hline 5 & EBF1 & rs1432679 & G & 0.631 & 0.642 & $1.05(0.89,1.24)$ & 0.08 & 0.558 & 1.07 & 0.931 \\
\hline 6 & $\mathrm{FOXQ}_{1}{ }^{+}$ & rs11242675 & A & 0.597 & 0.633 & $1.15(0.98,1.35)$ & 0.08 & 0.088 & - & - \\
\hline 6 & ECHDC1/RNF146 & rs2180341 & G & 0.181 & 0.198 & $1.09(0.90,1.33)$ & 0.10 & 0.365 & 1.31 & 0.100 \\
\hline 6 & RANBP9 & rs204247 & G & 0.588 & 0.611 & $1.10(0.94,1.29)$ & 0.08 & 0.248 & 1.05 & 0.911 \\
\hline 6 & FAM46A & rs17529111 & G & 0.218 & 0.206 & $0.92(0.75,1.12)$ & 0.10 & 0.404 & 1.06 & 0.675 \\
\hline 6 & ESR1 & rs3757318 & A & 0.276 & 0.316 & $1.20(1.01,1.42)$ & 0.09 & 0.039 & 1.04 & 0.790 \\
\hline 6 & $\mathrm{ESR} 1^{\ddagger}$ & rs2046210 & A & 0.380 & 0.434 & $1.25(1.06,1.46)$ & 0.08 & 0.008 & 1.27 & 0.970 \\
\hline 7 & ARHGEF5 & rs720475 & A & 0.046 & 0.041 & $0.90(0.61,1.33)$ & 0.20 & 0.596 & 0.94 & 0.941 \\
\hline 8 & RPL17P33 & rs9693444 & A & 0.282 & 0.288 & $1.04(0.87,1.24)$ & 0.09 & 0.691 & 1.07 & 0.977 \\
\hline 8 & $8 q 24$ & rs13281615 & G & 0.502 & 0.500 & $0.99(0.84,1.16)$ & 0.08 & 0.872 & 1.07 & 0.215 \\
\hline 8 & $8 q 24$ & rs1562430 & C & 0.181 & 0.184 & $1.03(0.83,1.27)$ & 0.11 & 0.820 & 0.87 & 0.273 \\
\hline 9 & CDKN2A & rs1011970 & A & 0.096 & 0.095 & $0.98(0.75,1.28)$ & 0.14 & 0.875 & 1.07 & 0.639 \\
\hline 9 & KLF4 & rs10759243 & A & 0.431 & 0.476 & $1.20(1.02,1.41)$ & 0.08 & 0.027 & 1.06 & 0.790 \\
\hline 9 & KLF4 & rs865686 & C & 0.057 & 0.067 & $1.19(0.87,1.64)$ & 0.16 & 0.275 & 0.90 & 0.150 \\
\hline 10 & ZNF365 & rs10822013 & $\mathrm{T}$ & 0.500 & 0.517 & $1.07(0.91,1.25)$ & 0.08 & 0.409 & 1.08 & 0.387 \\
\hline 10 & ZNF365 & rs10995190 & A & 0.012 & 0.013 & $1.14(0.57,2.30)$ & 0.36 & 0.713 & 1.06 & 0.350 \\
\hline 10 & ZMIZ1 & rs704010 & A & 0.369 & 0.397 & $1.12(0.95,1.33)$ & 0.08 & 0.169 & 1.08 & 0.473 \\
\hline 10 & $\mathrm{FGFR2}^{\ddagger}$ & rs1219648 & G & 0.404 & 0.427 & $1.08(0.92,1.27)$ & 0.08 & 0.343 & 1.14 & 0.560 \\
\hline 10 & FGFR2 & rs2981582 & A & 0.338 & 0.370 & $1.14(0.96,1.34)$ & 0.08 & 0.128 & 1.26 & 0.451 \\
\hline 11 & LSP1 & rs3817198 & G & 0.095 & 0.108 & $1.14(0.89,1.46)$ & 0.13 & 0.311 & 1.07 & 0.931 \\
\hline 11 & DKFZp761E198/OVOL1/SNX32/CFL1 & rs3903072 & A & 0.210 & 0.175 & $0.81(0.66,0.99)$ & 0.10 & 0.039 & 0.95 & 0.268 \\
\hline 11 & BARX2 & rs11820646 & A & 0.489 & 0.509 & $1.09(0.93,1.28)$ & 0.08 & 0.278 & 0.95 & 0.574 \\
\hline 12 & ATF7IP & rs12422552 & C & 0.273 & 0.325 & $1.29(1.08,1.53)$ & 0.09 & 0.004 & 1.06 & 0.128 \\
\hline 12 & PTHLH & rs10771399 & G & 0.192 & 0.173 & $0.88(0.71,1.08)$ & 0.11 & 0.221 & 0.86 & 0.729 \\
\hline 12 & NTN4 & rs17356907 & G & 0.253 & 0.247 & $0.98(0.82,1.18)$ & 0.09 & 0.839 & 0.91 & 0.604 \\
\hline 14 & PAX9/SLC25A21 & rs2236007 & A & 0.297 & 0.255 & $0.83(0.69,0.98)$ & 0.09 & 0.031 & 0.92 & 0.469 \\
\hline 14 & CCDC88C & rs941764 & G & 0.126 & 0.140 & $1.13(0.90,1.42)$ & 0.12 & 0.308 & 1.06 & 0.931 \\
\hline
\end{tabular}


Table 2 The rare allele frequencies of 51 single nucleotide polymorphisms (SNPs) in breast cancer patients and control subjects and their association with risk of breast cancer, The Singapore Chinese Health Study, 1993 to 1998 (Continued)

\begin{tabular}{|c|c|c|c|c|c|c|c|c|c|c|}
\hline 16 & TOX3 & rs4784227 & $\mathrm{T}$ & 0.245 & 0.274 & $1.17(0.97,1.41)$ & 0.09 & 0.098 & 1.23 & 0.574 \\
\hline 16 & TOX3 & rs3112612 & G & 0.228 & 0.210 & $0.90(0.74,1.10)$ & 0.10 & 0.300 & 1.13 & 0.066 \\
\hline 16 & CDYL2 & rs13329835 & G & 0.053 & 0.054 & $1.02(0.70,1.46)$ & 0.18 & 0.938 & 1.09 & 0.351 \\
\hline 16 & MIR1972-2/FTO & rs17817449 & $C$ & 0.140 & 0.118 & $0.83(0.66,1.06)$ & 0.12 & 0.134 & 0.93 & 0.079 \\
\hline 18 & $\mathrm{AQP}_{4}^{\ddagger}$ & rs527616 & G & 0.267 & 0.266 & $0.99(0.83,1.19)$ & 0.09 & 0.951 & 0.98 & 0.805 \\
\hline 18 & CHST9 & rs1436904 & C & 0.486 & 0.509 & $1.09(0.93,1.28)$ & 0.08 & 0.287 & 0.96 & 0.225 \\
\hline 19 & C19orf61:KCNN4:LYPD5:ZNF283 & rs3760982 & A & 0.136 & 0.148 & $1.10(0.87,1.38)$ & 0.12 & 0.437 & 1.06 & 0.994 \\
\hline 21 & NRIP1 & rs2823093 & $A$ & 0.035 & 0.032 & $0.90(0.57,1.40)$ & 0.23 & 0.631 & 0.92 & 0.994 \\
\hline
\end{tabular}

${ }^{\dagger} \mathrm{A}$ pooled odds ratio (pOR) was not obtained for rs 11242675 due to significant heterogeneity with other published studies; ${ }^{\ddagger}$ a pOR with the Asian studies was obtained due to heterogeneity with the results of European studies." $P$ value was derived from conditional logistic regression analysis. Chr, chromosome; RAF, risk allele frequency; FDR, false discovery rate.

Table 3 The relation for genetic risk score and established conventional risk factors with risk of breast cancer, The Singapore Chinese Health Study, 1993 to 1998

\begin{tabular}{|c|c|c|c|c|c|c|c|c|}
\hline Variable & $\begin{array}{l}\text { Case } \\
(\mathrm{n}=411) \\
n(\%)\end{array}$ & $\begin{array}{l}\text { Control } \\
(n=1,212), \\
n(\%)\end{array}$ & OR $(95 \% \mathrm{CI})$ & $P$ value & $\begin{array}{l}\text { Adjusted } \\
\text { OR }(95 \% \mathrm{Cl})^{\Phi}\end{array}$ & $P$ value & $\begin{array}{l}\text { Adjusted } \\
\text { OR }(95 \% \mathrm{Cl})^{\ddagger}\end{array}$ & $P$ value \\
\hline \multicolumn{9}{|c|}{ Genetic risk score, quartiles (range), mean } \\
\hline First (32.4-43.6), 40.4 & $80(19.5)$ & $326(26.9)$ & 1.00 (ref) & & 1.00 (ref) & & 1.00 (ref) & \\
\hline Second (43.6-47.1), 45.4 & $96(23.4)$ & $310(25.6)$ & $1.26(0.90,1.75)$ & 0.178 & $1.25(0.90,1.75)$ & 0.182 & $1.26(0.90,1.76)$ & 0.174 \\
\hline Third (47.1-50.6), 48.9 & $109(26.5)$ & $296(24.4)$ & $1,47(1.06,2.04)$ & 0.020 & $1.49(1.07,2.06)$ & 0.017 & $1.47(1.06,2.04)$ & 0.022 \\
\hline Fourth (50.6-65.8), 53.6 & $126(30.7)$ & $280(23.1)$ & $1.78(1.29,2.44)$ & $<0.001$ & $1.74(1.26,2.40)$ & 0.001 & $1.75(1.27,2.41)$ & 0.001 \\
\hline$P$ trend & & & $1.21(1.09,1.33)$ & $<0.001$ & $1.20(1.09,1.33)$ & $<0.001$ & $1.20(1.08,1.33)$ & $<0.001$ \\
\hline \multicolumn{9}{|c|}{ Age at first live birth, years } \\
\hline$<20$ & $56(13.6)$ & $212(17.5)$ & 1.00 (ref) & & 1.00 (ref) & & 1.00 (ref) & \\
\hline $20-24$ & $129(31.4)$ & $458(37.8)$ & $1.11(0.77,1.59)$ & 0.571 & $1.04(0.72,1.50)$ & 0.823 & $1.05(0.73,1.51)$ & 0.804 \\
\hline 25-29 or null & $175(42.6)$ & $416(34.3)$ & $1.67(1.16,2.39)$ & 0.005 & $1.51(1.04,2.18)$ & 0.030 & $1.49(1.03,2.15)$ & 0.036 \\
\hline$\geq 30$ & $51(12.4)$ & $126(10.4)$ & $1.62(1.03,2.55)$ & 0.038 & $1.46(0.92,2.31)$ & 0.111 & $1.49(1.03,2.29)$ & 0.131 \\
\hline$P$ trend & & & $1.25(1.09,1.42)$ & 0.001 & $1.20(1.05,1.38)$ & 0.008 & $1.19(1.04,1.37)$ & 0.011 \\
\hline \multicolumn{9}{|l|}{ Age at menarche, years } \\
\hline$\geq 14$ & $160(38.9)$ & $540(44.6)$ & 1.00 (ref) & & 1.00 (ref) & & 1.00 (ref) & \\
\hline $12-13$ & $180(43.8)$ & $484(39.9)$ & $1.29(1.00,1.66)$ & 0.049 & $1.21(0.93,1.56)$ & 0.151 & $1.23(0.94,1.60)$ & 0.126 \\
\hline$<12$ & $71(17.3)$ & $188(15.5)$ & $1.34(0.95,1.89)$ & 0.097 & $1.20(0.84,1.71)$ & 0.312 & $1.19(0.83,1.71)$ & 0.345 \\
\hline$P$ trend & & & $1.18(1.00,1.39)$ & 0.048 & $1.12(0.94,1.32)$ & 0.208 & $1.11(0.94,1.33)$ & 0.220 \\
\hline \multicolumn{9}{|l|}{ Family history } \\
\hline No & $400(97.3)$ & $1196(98.7)$ & 1.00 (ref) & & 1.00 (ref) & & 1.00 (ref) & \\
\hline Yes & $11(2.7)$ & $16(1.3)$ & $2.11(0.97,4.61)$ & 0.061 & $2.06(0.94,4.52)$ & 0.071 & $1.78(0.79,4.00)$ & 0.162 \\
\hline \multicolumn{9}{|l|}{ Past breast biopsy, n (\%) } \\
\hline No & 401 (97.6) & 1193 (98.4) & 1.00 (ref) & & 1.00 (ref) & & 1.00 (ref) & \\
\hline Yes & $10(2.4)$ & $19(1.6)$ & $1.55(0.69,3.48)$ & 0.288 & $1.36(0.60,3.08)$ & 0.462 & $1.36(0.58,3.20)$ & 0.475 \\
\hline \multicolumn{9}{|l|}{ Body mass index, $\mathrm{kg} / \mathrm{m}^{2}$} \\
\hline$<20$ & $51(12.4)$ & $167(13.8)$ & 1.00 (ref) & & 1.00 (ref) & & 1.00 (ref) & \\
\hline 20 to $<24$ & $216(52.6)$ & $659(54.4)$ & $1.09(0.77,1.54)$ & 0.632 & $1.11(0.78,1.58)$ & 0.562 & $1.16(0.81,1.66)$ & 0.423 \\
\hline 24 to $<28$ & $102(24.8)$ & $305(25.2)$ & $1.10(0.75,1.62)$ & 0.610 & $1.12(0.76,1.64)$ & 0.558 & $1.15(0.78,1.70)$ & 0.488 \\
\hline 28 or higher & $42(10.2)$ & $81(6.7)$ & $1.74(1.07,2.85)$ & 0.027 & $1.83(1.12,3.01)$ & 0.016 & $1.99(1.21,3.29)$ & 0.007 \\
\hline$P$ trend & & & $1.14(0.99,1.31)$ & 0.067 & $1.15(1.00,1.33)$ & 0.048 & $1.17(1.02,1.35)$ & 0.031 \\
\hline
\end{tabular}

Adjusted for education; ${ }^{\ddagger}$ adjusted for education and all other factors in the table. OR, odds ratio; $\mathrm{Cl}$, confidence interval. 


\begin{tabular}{|c|c|c|c|c|c|c|}
\hline \multirow{2}{*}{$\begin{array}{l}\text { Five-year } \\
\text { risk without } \\
\text { GRS (\%) } \\
\end{array}$} & \multicolumn{6}{|c|}{ Five-year risk with GRS (\%) } \\
\hline & $<1.0$ & $1.0-<1.5$ & $1.5-<2.0$ & $2.0-<2.5$ & $\geq 2.5$ & Tota \\
\hline \multicolumn{7}{|l|}{$<1.0$} \\
\hline Control & 511 & 84 & 0 & 0 & 0 & 595 \\
\hline Case & 109 & 46 & 0 & 0 & 0 & 155 \\
\hline \multicolumn{7}{|l|}{$1.0-<1.5$} \\
\hline Control & 90 & 356 & 33 & 0 & 0 & 479 \\
\hline Case & 36 & 123 & 39 & 0 & 0 & 198 \\
\hline \multicolumn{7}{|l|}{$1.5-<2.0$} \\
\hline Control & 0 & 53 & 50 & 12 & 0 & 115 \\
\hline Case & 0 & 13 & 19 & 12 & 0 & 44 \\
\hline \multicolumn{7}{|l|}{$2.0-<2.5$} \\
\hline Control & 0 & 0 & 12 & 3 & 1 & 16 \\
\hline Case & 0 & 0 & 4 & 2 & 3 & 9 \\
\hline \multicolumn{7}{|l|}{$>2.5$} \\
\hline Control & 0 & 0 & 0 & 2 & 5 & 7 \\
\hline Case & 0 & 0 & 0 & 1 & 4 & 5 \\
\hline \multicolumn{7}{|l|}{ Total } \\
\hline Control & 601 & 493 & 94 & 18 & 6 & 1,212 \\
\hline Case & 145 & 182 & 62 & 15 & 7 & 411 \\
\hline
\end{tabular}

effects in the former [68]. Our study also supports the finding that the MAP3K SNP, rs889312, does not increase the risk of breast cancer among the Chinese $[31,38,56]$, contrary to that of European populations [7,33]. However, unlike the other studies $[7,8,31,33,37,38]$, statistical significance was not observed here for another well-established susceptibility loci containing FGFR2.

The OR of rs11242675 (FOXQ1) reported here was 1.15. This is contradictory to the findings of many published works, which have reported statistically significant protective effects, but the risk effect we found is supported by the most recent BCAC study [46]. As a result, significant heterogeneity was observed among the various studies and a pOR was not applicable. Forkhead box Q1 (FOXQ1) is a transcription factor found on the 6p25 locus. Overexpression of the protein has been shown to enhance tumorigenicity and tumor growth through its angiogenic and anti-apoptotic properties [69]. Its novel role in the metastasis of breast cancer has also been suggested [70]. In view of a plausible biological function of FOXQ1 in promoting cancer aggression, as well as marginal statistical significance that was a likely consequence of small sample size, rs11242675 was included in the GRS for risk assessment.
Another SNP that was also considered in the GRS due to its marginally significant $P$ value $(P=0.098)$ was rs4784227. Rs4784227 is situated at 16q12.1 [71] and has been predicted to interfere with the affinity of FOXA1, an essential component of ESR $\alpha$ signaling [72], to its binding site [73]. Its position in a regulatory region that interacts with the TOX3 promoter enables it to disrupt the expression of this gene, which in turn alters chromatin structure and DNA-protein binding patterns essential for cell survival [71]. An OR of 1.17 was seen in our study. This effect size and direction were similar to the findings of others thus a pOR was used for GRS computation.

It was observed, in Figure 2, that the marginal improvement in model performance was not proportional to the increase in additional SNPs used. Although the discovery of additional SNPs do not drastically improve the assessment of breast cancer risk, this is expected since the first few new SNPs discovered would have been associated with much larger effect sizes. Also, as the cost of genotyping continues to decrease, we expect the use of additional SNPs in risk assessment to be cost-effective in the near future.

This study has several strengths. The study was nested within a population-based prospective cohort that provides the use of questionnaire data collected before the occurrence of breast cancer to reduce recall and reverse causality bias. The inclusion of genetic variants in risk assessment is advantageous as it is not subjected to time-dependent errors in measurement, unlike environmental exposures such as BMI or smoking. We have also shown the strength of the association between GRS and breast cancer risk; it remains virtually unchanged even after all other established risk factors have been considered, highlighting the importance of genetics in this aspect.

There are also several limitations in our study. The small sample size of approximately 1,600 women has made it difficult to attain statistical significance for most of the SNPs that were identified in GWAS studies. Nevertheless, the direction of the effects of most SNPs was consistent with the published literature. As all the subjects recruited were Chinese women, this could restrict the generalizability of our results. Studies will need to be conducted in larger populations and among women of other ethnicities to validate the effect of these polymorphisms. We were not able to consider two factors in this study: 1) the presence of copy number variations (CNVs) and their potential effects on breast cancer risk and 2) the various subtypes of the disease. Given the proximity of some SNPs to CNV regions [74], and the relation between CNVs and familial breast cancer [75], an effect of CNVs on risk of disease is not unlikely. However, modeling this poses difficulties and may not 


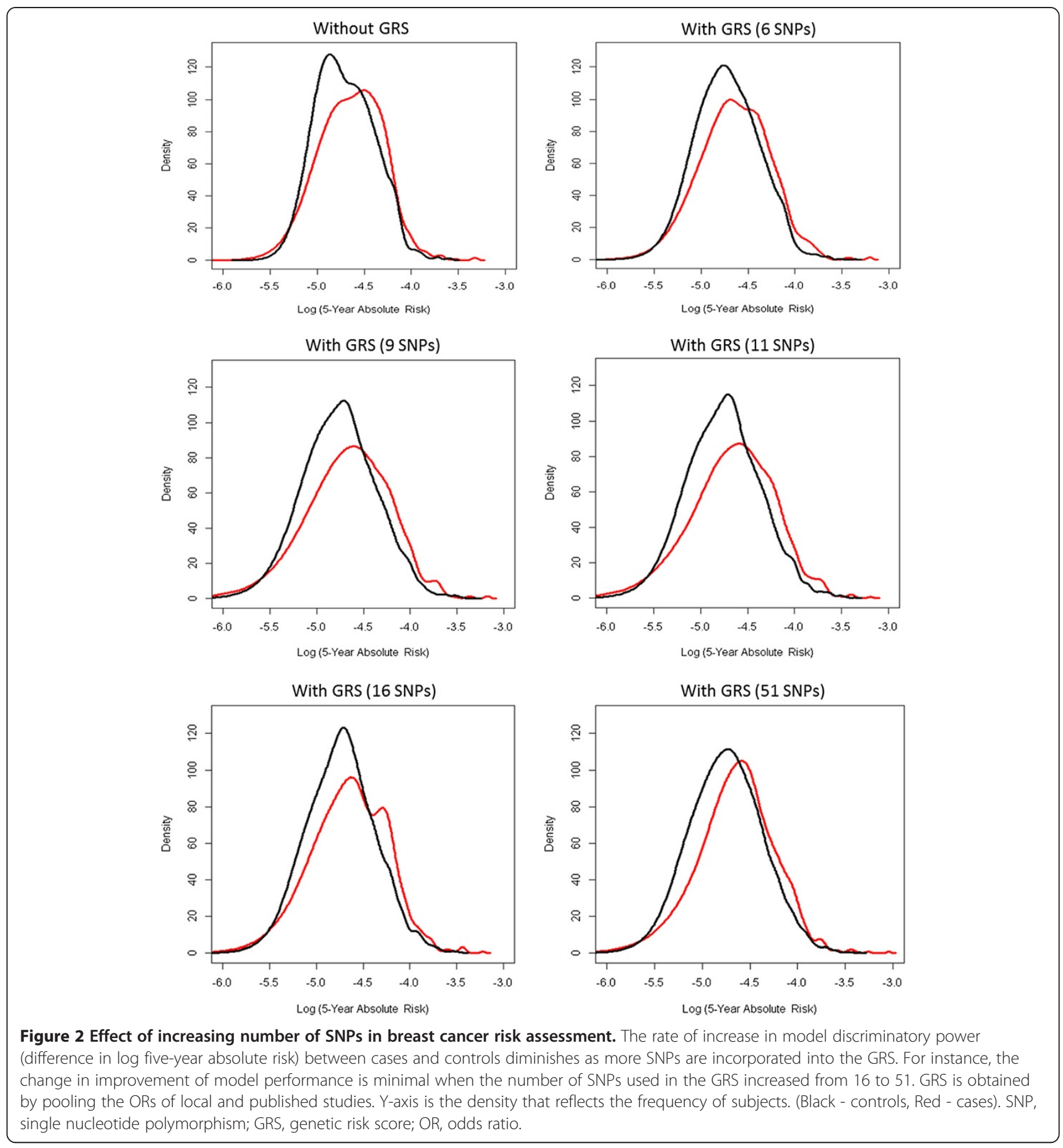

alter the results substantially [74]. Although further analysis by disease subtype would have been ideal, we were restricted by the study's limited sample size and power. Finally, the breast cancer cases included in this study from the cohort had a higher prevalence for positive family history of breast cancer compared to cases that were not included in this study, although this prevalence was still generally low (2.7\%).

\section{Conclusions}

In summary, we have shown the extent to which 51 SNPs may improve the current assessment of breast cancer risk. Most of the SNPs identified in other Western and Asian studies have presented similar effect sizes in our Singapore Chinese population. Despite conferring minimal increase in risk, individual genetic variants when considered cumulatively can result in considerable effects, leading to improved 
risk stratification. By including a genetic component for risk assessment, more targeted measures of prevention and screening can be implemented. For countries such as Singapore where breast cancer incidence is relatively low and mammography screening is not as well-received, costefficiency and ethical issues can be more aptly addressed.

\section{Additional file}

Additional file 1: Table S1. The corresponding individual and pooled ORs from published GWAS studies for 51 SNPs. This table presents the individual and pooled ORs, as well as FDR-corrected $P$-het of each SNP from published studies. The pooled ORs for each SNP were obtained from published studies only.

\section{Abbreviations}

AUC: area under the receiver operating characteristic curve; BCAC: Breast Cancer Association Consortium; BMI: body mass index; CHB: Han Chinese in Beijing; Cl: confidence interval; CNV: copy number variation; ESRa: estrogen receptor alpha; FDR: false discovery rate; GRS: genetic risk score; GWAS: genome-wide association studies; MAF: minor allele frequency; NRI: net reclassification improvement; OR: odds ratio; pOR: pooled odds ratio; RAF: risk allele frequency; SCHS: Singapore Chinese Health Study; SGVP: Singapore Genome Variation Project; SNP: single nucleotide polymorphism.

\section{Competing interests}

The authors declare that they have no competing interests.

\section{Authors' contributions}

$\mathrm{MH}$ directed the study and was responsible for the study design. CPLL performed data management, statistical analyses, interpretation of results and drafted the initial manuscript. Al managed the genotype data and performed statistical analyses. AS was involved in the statistical analyses and interpretation of results. $J L$ administrated the genotyping analysis. JY and WPK were responsible for biospecimen and data collection for the Singapore Chinese Health Study cohort, on which this study is based. All authors read, critically revised and approved the final manuscript.

\section{Acknowledgements}

We thank Siew-Hong Low of the National University of Singapore for supervising the field work of the Singapore Chinese Health Study, and Kazuko Arakawa and Renwei Wang for the development and management of the cohort study database. We also thank the Singapore Cancer Registry in Singapore for assistance with the identification of cancer cases via database linkages. Finally, we acknowledge the founding principal investigator of the Singapore Chinese Health Study - Mimi C. Yu. The Singapore Chinese Health Study was supported by grants R01 CA55069, R35 CA53890, R01 CA80205, and R01 CA144034 from the National Cancer Institute, Bethesda, Maryland, USA. CPLL was supported by the NUS Graduate School for Integrative Sciences and Engineering (NGS) Scholarship. Al was supported by the A*STAR Singapore International Graduate Award (SINGA).

\section{Author details}

${ }^{1}$ NUS Graduate School for Integrative Sciences and Engineering, National University of Singapore, 21 Lower Kent Ridge Road, Singapore 119077, Singapore. ${ }^{2}$ Saw Swee Hock School of Public Health, National University of Singapore, 21 Lower Kent Ridge Road, Singapore 119077, Singapore. ${ }^{3}$ Human Genetics, Genome Institute of Singapore, 60 Biopolis Street, Singapore 138672, Singapore. ${ }^{4}$ Department of Mathematics and Statistics, La Trobe University, Kingsbury Drive, Bundoora, VIC 3086, Australia. ${ }^{5}$ Division of Cancer Control and Population Sciences, University of Pittsburgh Cancer Institute; and Department of Epidemiology, Graduate School of Public Health, University of Pittsburgh, 4200 Fifth Avenue, Pittsburgh, PA 15260, USA. ${ }^{6}$ Duke-NUS Graduate Medical School Singapore, 2 Jalan Bukit Merah, Singapore 169547, Singapore. ${ }^{7}$ Department of Surgery, National University Hospital, 5 Lower Kent Ridge Road, Singapore 119074, Singapore.
${ }^{8}$ Department of Medical Epidemiology and Biostatistics, Karolinska Institutet, Nil, Stockholm SE-171 77, Sweden.

Received: 6 August 2013 Accepted: 4 June 2014

Published: 18 June 2014

\section{References}

1. Gail MH, Brinton LA, Byar DP, Corle DK, Green SB, Schairer C, Mulvihill JJ: Projecting individualized probabilities of developing breast cancer for white females who are being examined annually. J Natl Cancer Inst 1989, 81:1879-1886.

2. Breast cancer and hormonal contraceptives: collaborative reanalysis of individual data on 53297 women with breast cancer and 100239 women without breast cancer from 54 epidemiological studies. Collaborative Group on Hormonal Factors in Breast Cancer. Lancet 1996, 347:1713-1727.

3. Breast cancer and hormone replacement therapy: collaborative reanalysis of data from 51 epidemiological studies of 52,705 women with breast cancer and 108,411 women without breast cancer. Collaborative Group on Hormonal Factors in Breast Cancer. Lancet 1997 350:1047-1059.

4. McPherson K, Steel CM, Dixon JM: ABC of breast diseases. Breast cancer-epidemiology, risk factors, and genetics. BMJ 2000, 321:624-628.

5. Miki Y, Swensen J, Shattuck-Eidens D, Futreal PA, Harshman K, Tavtigian S, Liu Q, Cochran C, Bennett LM, Ding W, Bell R, Rosenthal J, Hussey C, Tran T, McClure M, Frye C, Hattier T, Phelps R, Haugen-Strano A, Katcher H, Yakumo K, Gholami Z, Shaffer D, Stone S, Bayer S, Wray C, Bogden R, Dayananth P, Ward J, Tonin $\mathrm{P}$, et al: A strong candidate for the breast and ovarian cancer susceptibility gene BRCA1. Science 1994, 266:66-71.

6. Wooster R, Bignell G, Lancaster J, Swift S, Seal S, Mangion J, Collins N, Gregory S, Gumbs C, Micklem G: Identification of the breast cancer susceptibility gene BRCA2. Nature 1995, 378:789-792.

7. Easton DF, Pooley KA, Dunning AM, Pharoah PD, Thompson D, Ballinger DG, Struewing JP, Morrison J, Field H, Luben R, Wareham N, Ahmed S, Healey CS, Bowman R, Meyer KB, Haiman CA, Kolonel LK, Henderson BE, Marchand LL, Brennan P, Sangrajrang S, Gaborieau V, Odefrey F, Shen CY, Wu PE, Wang HC, Eccles D, Evans DG, Peto J, The SEARCH collaborators, et al: Genome-wide association study identifies novel breast cancer susceptibility loci. Nature 2007, 447:1087-1093.

8. Turnbull C, Ahmed S, Morrison J, Pernet D, Renwick A, Maranian M, Seal S, Ghoussaini M, Hines S, Healey CS, Hughes D, Warren-Perry M, Tapper W, Eccles D, Evans DG, Hooning M, Schutte M, van den Ouweland A, Houlston R, Ross G, Langford C, Pharoah PD, Stratton MR, Dunning AM, Rahman N, Easton DF, Breast Cancer Susceptibility Collaboration (UK): Genome-wide association study identifies five new breast cancer susceptibility loci. Nat Genet 2010, 42:504-507.

9. Meijers-Heijboer $H$, van den Ouweland A, Klijn J, Wasielewski M, de Snoo A, Oldenburg R, Hollestelle A, Houben M, Crepin E, van Veghel-Plandsoen M, Elstrodt F, van Duijn C, Bartels C, Meijers C, Schutte M, McGuffog L, Thompson D, Easton DF, Sodha N, Seal S, Barfoot R, Mangion J, Chang-Claude J, Eccles D, Eeles R, Evans DG, Houlston R, Murday V, Narod S, Peretz T, et al: Low-penetrance susceptibility to breast cancer due to $\left.\mathrm{CHEK} 2{ }^{*}\right) 1100 \mathrm{del} C$ in noncarriers of BRCA1 or BRCA2 mutations. Nat Genet 2002, 31:55-59.

10. Renwick A, Thompson D, Seal S, Kelly P, Chagtai T, Ahmed M, North B, Jayatilake H, Barfoot R, Spanova K, McGuffog L, Evans DG, Eccles D, Easton DF, Stratton MR, Rahman N, Breast Cancer Susceptibility Collaboration (UK): ATM mutations that cause ataxia-telangiectasia are breast cancer susceptibility alleles. Nat Genet 2006, 38:873-875.

11. Seal S, Thompson D, Renwick A, Elliott A, Kelly P, Barfoot R, Chagtai T, Jayatilake H, Ahmed M, Spanova K, North B, McGuffog L, Evans DG, Eccles D, Easton DF, Stratton MR, Rahman N, Breast Cancer Susceptibility Collaboration (UK): Truncating mutations in the Fanconi anemia J gene BRIP1 are low-penetrance breast cancer susceptibility alleles. Nat Genet 2006, 38:1239-1241.

12. Rahman N, Seal S, Thompson D, Kelly P, Renwick A, Elliott A, Reid S, Spanova K, Barfoot R, Chagtai T, Jayatilake H, McGuffog L, Hanks S, Evans DG, Eccles D, Easton DF, Stratton MR, Breast Cancer Susceptibility Collaboration (UK): PALB2, which encodes a BRCA2-interacting protein, is a breast cancer susceptibility gene. Nat Genet 2007, 39:165-167.

13. Antoniou AC, Easton DF: Models of genetic susceptibility to breast cancer. Oncogene 2006, 25:5898-5905. 
14. Antoniou AC, Pharoah PD, McMullan G, Day NE, Stratton MR, Peto J, Ponder BJ, Easton DF: A comprehensive model for familial breast cancer incorporating BRCA1, BRCA2 and other genes. Br J Cancer 2002, 86:76-83.

15. Antoniou AC, Pharoah PP, Smith P, Easton DF: The BOADICEA model of genetic susceptibility to breast and ovarian cancer. Br J Cancer 2004, 91:1580-1590.

16. Easton DF: How many more breast cancer predisposition genes are there? Breast Cancer Res 1999, 1:14-17.

17. Ghoussaini M, Pharoah PD: Polygenic susceptibility to breast cancer: current state-of-the-art. Future Oncol 2009, 5:689-701.

18. Lichtenstein P, Holm NV, Verkasalo PK, Iliadou A, Kaprio J, Koskenvuo M, Pukkala E, Skytthe A, Hemminki K: Environmental and heritable factors in the causation of cancer-analyses of cohorts of twins from Sweden, Denmark, and Finland. N Engl J Med 2000, 343:78-85.

19. Nelson NJ: Migrant studies aid the search for factors linked to breast cancer risk. J Natl Cancer Inst 2006, 98:436-438.

20. Collins FS, McKusick VA: Implications of the Human Genome Project for medical science. JAMA 2001, 285:540-544.

21. Cummings SR, Tice JA, Bauer S, Browner WS, Cuzick J, Ziv E, Vogel V, Shepherd J, Vachon C, Smith-Bindman R, Kerlikowske K: Prevention of breast cancer in postmenopausal women: approaches to estimating and reducing risk. J Natl Cancer Inst 2009, 101:384-398.

22. Parmigiani G, Berry D, Aguilar O: Determining carrier probabilities for breast cancer-susceptibility genes BRCA1 and BRCA2. Am J Hum Genet 1998, 62:145-158.

23. Claus EB, Risch N, Thompson WD: Autosomal dominant inheritance of early-onset breast cancer, Implications for risk prediction. Cancer 1994, 73:643-651.

24. Gail MH, Mai PL: Comparing breast cancer risk assessment models. J Natl Cancer Inst 2010, 102:665-668.

25. Wacholder S, Hartge P, Prentice R, Garcia-Closas M, Feigelson HS, Diver WR, Thun MJ, Cox DG, Hankinson SE, Kraft P, Rosner B, Berg CD, Brinton LA Lissowska J, Sherman ME, Chlebowski R, Kooperberg C, Jackson RD, Buckman DW, Hui P, Pfeiffer R, Jacobs KB, Thomas GD, Hoover RN, Gail MH Chanock SJ, Hunter DJ: Performance of common genetic variants in breast-cancer risk models. N Engl J Med 2010, 362:986-993.

26. Hartman M, Suo C, Lim WY, Miao H, Teo YY, Chia KS: Ability to predict breast cancer in Asian women using a polygenic susceptibility model. Breast Cancer Res Treat 2011, 127:805-812.

27. Pharoah PD, Antoniou AC, Easton DF, Ponder BA: Polygenes, risk prediction, and targeted prevention of breast cancer. N Engl J Med 2008, 358:2796-2803.

28. Jemal A, Bray F, Center MM, Ferlay J, Ward E, Forman D: Global cancer statistics. CA Cancer J Clin 2011, 61:69-90.

29. Wee SB: The case for breast cancer screening in Singapore. Singapore Med J 2002, 43:221-223.

30. Sim X, Ali RA, Wedren S, Goh DL, Tan CS, Reilly M, Hall P, Chia KS: Ethnic differences in the time trend of female breast cancer incidence: Singapore, 1968-2002. BMC Cancer 2006, 6:261.

31. Long J, Shu XO, Cai Q, Gao YT, Zheng Y, Li G, Li C, Gu K, Wen W, Xiang YB, Lu W, Zheng W: Evaluation of breast cancer susceptibility loci in Chinese women. Cancer Epidemiol Biomarkers Prev 2010, 19:2357-2365.

32. Ahmed S, Thomas G, Ghoussaini M, Healey CS, Humphreys MK, Platte R, Morrison J, Maranian M, Pooley KA, Luben R, Eccles D, Evans DG, Fletcher O, Johnson N, dos Santos Silva I, Peto J, Stratton MR, Rahman N, Jacobs K, Prentice R, Anderson GL, Rajkovic A, Curb JD, Ziegler RG, Berg CD, Buys SS, McCarty CA, Feigelson HS, Calle EE, Thun MJ, et al: Newly discovered breast cancer susceptibility loci on 3p24 and 17q23.2. Nat Genet 2009, 41:585-590

33. Thomas $G$, Jacobs KB, Kraft P, Yeager M, Wacholder S, Cox DG, Hankinson SE, Hutchinson A, Wang Z, Yu K, Chatterjee N, Garcia-Closas M, Gonzalez-Bosquet J, Prokunina-Olsson L, Orr N, Willett WC, Colditz GA, Ziegler RG, Berg CD, Buys SS, McCarty CA, Feigelson HS, Calle EE, Thun MJ, Diver R, Prentice R, Jackson R, Kooperberg C, Chlebowski R, Lissowska J, et al: A multistage genome-wide association study in breast cancer identifies two new risk alleles at 1p11.2 and 14q24.1 (RAD51L1). Nat Genet 2009, 41:579-584.

34. Gold B, Kirchhoff T, Stefanov S, Lautenberger J, Viale A, Garber J, Friedman E, Narod S, Olshen AB, Gregersen P, Kosarin K, Olsh A, Bergeron J, Ellis NA Klein RJ, Clark AG, Norton L, Dean M, Boyd J, Offit K: Genome-wide association study provides evidence for a breast cancer risk locus at 6q22.33. Proc Natl Acad Sci U S A 2008, 105:4340-4345.
35. Stacey SN, Manolescu A, Sulem P, Rafnar T, Gudmundsson J, Gudjonsson SA, Masson G, Jakobsdottir M, Thorlacius S, Helgason A, Aben KK, Strobbe L, Albers-Akkers MT, Swinkels DW, Henderson BE, Kolonel LN, Le Marchand L, Millastre E, Andres R, Godino J, Garcia-Prats MD, Polo E, Tres A, Mouy M, Saemundsdottir J, Backman VM, Gudmundsson L, Kristjansson K, Bergthorsson JT, Kostic J, et al: Common variants on chromosomes 2q35 and $16 q 12$ confer susceptibility to estrogen receptor-positive breast cancer. Nat Genet 2007, 39:865-869.

36. Hunter DJ, Kraft $P$, Jacobs KB, Cox DG, Yeager M, Hankinson SE, Wacholder $S$, Wang Z, Welch R, Hutchinson A, Wang J, Yu K, Chatterjee N, Orr N, Willett WC, Colditz GA, Ziegler RG, Berg CD, Buys SS, McCarty CA, Feigelson HS, Calle EE, Thun MJ, Hayes RB, Tucker M, Gerhard DS, Fraumeni JF Jr, Hoover RN, Thomas G, Chanock SJ: A genome-wide association study identifies alleles in FGFR2 associated with risk of sporadic postmenopausal breast cancer. Nat Genet 2007, 39:870-874.

37. Sueta A, Ito H, Kawase T, Hirose K, Hosono S, Yatabe Y, Tajima K, Tanaka H, Iwata $\mathrm{H}$, Iwase $\mathrm{H}$, Matsuo $\mathrm{K}: \mathrm{A}$ genetic risk predictor for breast cancer using a combination of low-penetrance polymorphisms in a Japanese population. Breast Cancer Res Treat 2012, 132:711-721.

38. Zheng W, Long J, Gao YT, Li C, Zheng Y, Xiang YB, Wen W, Levy S, Deming SL, Haines JL, Gu K, Fair AM, Cai Q, Lu W, Shu XO: Genome-wide association study identifies a new breast cancer susceptibility locus at 6q25.1. Nat Genet 2009, 41:324-328.

39. Zheng W, Zhang B, Cai Q, Sung H, Michailidou K, Shi J, Choi JY, Long J, Dennis J, Humphreys MK, Wang Q, Lu W, Gao YT, Li C, Cai H, Park SK, Yoo KY, Noh DY, Han W, Dunning AM, Benitez J, Vincent D, Bacot F, Tessier D, Kim SW, Lee MH, Lee JW, Lee JY, Xiang YB, Zheng Y, et al: Common genetic determinants of breast-cancer risk in East Asian women: a collaborative study of 23637 breast cancer cases and 25579 controls. Hum Mol Genet 2013, 22:2539-2550.

40. Hankin JH, Stram DO, Arakawa K, Park S, Low SH, Lee HP, Yu MC: Singapore Chinese Health Study: development, validation, and calibration of the quantitative food frequency questionnaire. Nutr Cancer 2001, 39:187-195.

41. Koh WP, Yuan JM, Sun CL, van den Berg D, Seow A, Lee HP, Yu MC: Angiotensin I-converting enzyme (ACE) gene polymorphism and breast cancer risk among Chinese women in Singapore. Cancer Res 2003 63:573-578.

42. Hindorff LA, MacArthur J, Morales J, Junkins HA, Hall PN, Klemm AK, Manolio TA: A catalog of published genome-wide association studies. Available at: [http://www.genome.gov/gwastudies]. Accessed Dec 2011.

43. Cai Q, Long J, Lu W, Qu S, Wen W, Kang D, Lee JY, Chen K, Shen H, Shen CY, Sung H, Matsuo K, Haiman CA, Khoo US, Ren Z, Iwasaki M, Gu K, Xiang YB, Choi JY, Park SK, Zhang L, Hu Z, Wu PE, Noh DY, Tajima K, Henderson $B E$, Chan KY, Su F, Kasuga Y, Wang W, et al: Genome-wide association study identifies breast cancer risk variant at 10q21.2: results from the Asia Breast Cancer Consortium. Hum Mol Genet 2011, 20:4991-4999.

44. Fletcher O, Johnson N, Orr N, Hosking FJ, Gibson LJ, Walker K, Zelenika D, Gut I, Heath S, Palles C, Coupland B, Broderick P, Schoemaker M, Jones M, Williamson J, Chilcott-Burns S, Tomczyk K, Simpson G, Jacobs KB, Chanock SJ, Hunter DJ, Tomlinson IP, Swerdlow A, Ashworth A, Ross G, dos Santos Silva I, Lathrop M, Houlston RS, Peto J: Novel breast cancer susceptibility locus at 9q31.2: results of a genome-wide association study. J Nat/ Cancer Inst 2011, 103:425-435.

45. Li J, Humphreys K, Heikkinen T, Aittomaki K, Blomqvist C, Pharoah PD, Dunning AM, Ahmed S, Hooning MJ, Martens JW, van den Ouweland AM, Alfredsson L, Palotie A, Peltonen-Palotie L, Irwanto A, Low HQ, Teoh GH, Thalamuthu A, Easton DF, Nevanlinna H, Liu J, Czene K, Hall P: A combined analysis of genome-wide association studies in breast cancer. Breast Cancer Res Treat 2011, 126:717-727.

46. Michailidou K, Hall P, Gonzalez-Neira A, Ghoussaini M, Dennis J, Milne RL, Schmidt MK, Chang-Claude J, Bojesen SE, Bolla MK, Breast and Ovarian Cancer Susceptibility Collaboration, Wang Q, Dicks E, Lee A, Turnbull C, Rahman N, Fletcher O, Peto J, Gibson L, Dos Santos Silva I, Nevanlinna H, Muranen TA, Aittomäki K, Blomqvist C, Czene K, Irwanto A, Liu J, Waisfisz Q Meijers-Heijboer $H$, Adank M, et al: Large-scale genotyping identifies 41 new loci associated with breast cancer risk. Nat Genet 2013, 45:353-361.

47. Altshuler DM, Gibbs RA, Peltonen L, Altshuler DM, Gibbs RA, Peltonen L, Dermitzakis E, Schaffner SF, Yu F, Peltonen L, Altshuler DM, Gibbs RA, Peltonen L, Dermitzakis E, Schaffner SF, Yu F, Peltonen L, Dermitzakis E, Bonnen PE, Altshuler DM, Gibbs RA, de Bakker PI, Deloukas P, Gabriel SB, Gwilliam R, Hunt S, Inouye M, Jia X, Palotie A, Parkin M, et al: Integrating 
common and rare genetic variation in diverse human populations. Nature 2010, 467:52-58.

48. Teo YY, Sim X, Ong RT, Tan AK, Chen J, Tantoso E, Small KS, Ku CS, Lee EJ, Seielstad M, Chia KS: Singapore Genome Variation Project: a haplotype map of three Southeast Asian populations. Genome Res 2009, 19:2154-2162.

49. Huedo-Medina TB, Sanchez-Meca J, Marin-Martinez F, Botella J: Assessing heterogeneity in meta-analysis: Q statistic or 12 index? Psychol Methods 2006, 11:193-206.

50. Hochberg Y, Benjamini Y: More powerful procedures for multiple significance testing. Stat Med 1990, 9:811-818.

51. Rasmussen-Torvik LJ, Li M, Kao WH, Couper D, Boerwinkle E, Bielinski SJ, Folsom AR, Pankow JS: Association of a fasting glucose genetic risk score with subclinical atherosclerosis: the Atherosclerosis Risk in Communities (ARIC) study. Diabetes 2011, 60:331-335.

52. Pencina MJ, D'Agostino RB Sr, D'Agostino RB Jr, Vasan RS: Evaluating the added predictive ability of a new marker: from area under the ROC curve to reclassification and beyond. Stat Med 2008, 27:157-172 discussion 207-112.

53. Efron B: Bootstrap methods: another look at the jackknife. The Ann Stat 1979, 7:1-26.

54. Zheng W, Wen W, Gao YT, Shyr Y, Zheng Y, Long J, Li G, Li C, Gu K, Cai Q Shu XO, Lu W: Genetic and clinical predictors for breast cancer risk assessment and stratification among Chinese women. J Natl Cancer Inst 2010, 102:972-981.

55. Dai J, Hu Z, Jiang Y, Shen $H$, Dong J, Ma H, Shen $H$ : Breast cancer risk assessment with five independent genetic variants and two risk factors in Chinese women. Breast Cancer Res 2012, 14:R17.

56. Chan M, Ji SM, Liaw CS, Yap YS, Law HY, Yoon CS, Wong CY, Yong WS, Wong NS, Ng R, Ong KW, Madhukumar P, Oey CL, Tan PH, Li HH, Ang P, $\mathrm{Ho}$ GH, Lee AS: Association of common genetic variants with breast cancer risk and clinicopathological characteristics in a Chinese population. Breast Cancer Res Treat 2012, 136:209-220.

57. Gail MH: Discriminatory accuracy from single-nucleotide polymorphisms in models to predict breast cancer risk. J Natl Cancer Inst 2008, 100:1037-1041.

58. Machiela MJ, Chen CY, Chen C, Chanock SJ, Hunter DJ, Kraft P: Evaluation of polygenic risk scores for predicting breast and prostate cancer risk. Genet Epidemiol 2011, 35:506-514.

59. Chatterjee N, Park JH, Caporaso N, Gail MH: Predicting the future of genetic risk prediction. Cancer Epidemiol Biomarkers Prev 2011, 20:3-8.

60. Darabi H, Czene K, Zhao W, Liu J, Hall P, Humphreys K: Breast cancer risk prediction and individualised screening based on common genetic variation and breast density measurement. Breast Cancer Res 2012, 14:R25.

61. Wu AH, Seow A, Arakawa K, Van Den Berg D, Lee HP, Yu MC: HSD17B1 and CYP17 polymorphisms and breast cancer risk among Chinese women in Singapore. Int J Cancer 2003, 104:450-457.

62. Yuan JM, Koh WP, Sun CL, Lee HP, Yu MC: Green tea intake, ACE gene polymorphism and breast cancer risk among Chinese women in Singapore. Carcinogenesis 2005, 26:1389-1394.

63. Anothaisintawee T, Teerawattananon Y, Wiratkapun C, Kasamesup V, Thakkinstian A: Risk prediction models of breast cancer: a systematic review of model performances. Breast Cancer Res Treat 2012, 133:1-10.

64. Cook NR: Use and misuse of the receiver operating characteristic curve in risk prediction. Circulation 2007, 115:928-935.

65. Janes H, Pepe MS, Gu W: Assessing the value of risk predictions by using risk stratification tables. Ann Intern Med 2008, 149:751-760.

66. Mealiffe ME, Stokowski RP, Rhees BK, Prentice RL, Pettinger M, Hinds DA: Assessment of clinical validity of a breast cancer risk model combining genetic and clinical information. J Natl Cancer Inst 2010, 102:1618-1627.

67. Cai Q, Wen W, Qu S, Li G, Egan KM, Chen K, Deming SL, Shen H, Shen CY, Gammon MD, Blot WJ, Matsuo K, Haiman CA, Khoo US, Iwasaki M, Santella RM, Zhang L, Fair AM, Hu Z, Wu PE, Signorello LB, Titus-Ernstoff L, Tajima K Henderson BE, Chan KY, Kasuga Y, Newcomb PA, Zheng H, Cui Y, Wang F et al: Replication and functional genomic analyses of the breast cancer susceptibility locus at $6 q 25.1$ generalize its importance in women of chinese, Japanese, and European ancestry. Cancer Res 2011, 71:1344-1355.

68. Hein R, Maranian M, Hopper JL, Kapuscinski MK, Southey MC, Park DJ, Schmidt MK, Broeks A, Hogervorst FB, Bueno-de-Mesquita HB, Muir KR, Lophatananon A, Rattanamongkongul S, Puttawibul P, Fasching PA, Hein A, Ekici AB, Beckmann MW, Fletcher O, Johnson N, dos Santos Silva I, Peto J, Sawyer E, Tomlinson I, Kerin M, Miller N, Marmee F, Schneeweiss A, Sohn C,
Burwinkel B, et al: Comparison of $6 \mathrm{q} 25$ breast cancer hits from Asian and European Genome Wide Association Studies in the Breast Cancer Association Consortium (BCAC). PLoS One 2012, 7:e42380.

69. Kaneda H, Arao T, Tanaka K, Tamura D, Aomatsu K, Kudo K, Sakai K, De Velasco MA, Matsumoto K, Fujita Y, Yamada Y, Tsurutani J, Okamoto I, Nakagawa K, Nishio K: FOXQ1 is overexpressed in colorectal cancer and enhances tumorigenicity and tumor growth. Cancer Res 2010, 70:2053-2063.

70. Zhang H, Meng F, Liu G, Zhang B, Zhu J, Wu F, Ethier SP, Miller F, Wu G: Forkhead transcription factor foxq1 promotes epithelial-mesenchyma transition and breast cancer metastasis. Cancer Res 2011, 71:1292-1301.

71. Long J, Cai Q, Shu XO, Qu S, Li C, Zheng Y, Gu K, Wang W, Xiang YB, Cheng J, Chen K, Zhang L, Zheng H, Shen CY, Huang CS, Hou MF, Shen H, Hu Z, Wang F, Deming SL, Kelley MC, Shrubsole MJ, Khoo US, Chan KY, Chan SY, Haiman CA, Henderson BE, Le Marchand L, Iwasaki M, Kasuga Y, et al: Identification of a functional genetic variant at $16 q 121$ for breast cancer risk: results from the Asia Breast Cancer Consortium. LoS Genet 2010, 6:e1001002.

72. Bernardo GM, Keri RA: FOXA1: a transcription factor with parallel functions in development and cancer. Biosci Rep 2012, 32:113-130.

73. Cowper-Sal Lari R, Zhang X, Wright JB, Bailey SD, Cole MD, Eeckhoute J, Moore JH, Lupien M: Breast cancer risk-associated SNPs modulate the affinity of chromatin for FOXA1 and alter gene expression. Nat Genet 2012, 44:1191-1198

74. Yu KD, Fang Q, Shao ZM: Combining accurate genetic and clinical information in breast cancer risk model. Breast Cancer Res Treat 2011, 128:283-285.

75. Frank B, Bermejo JL, Hemminki K, Sutter C, Wappenschmidt B, Meindl A, Kiechle-Bahat M, Bugert P, Schmutzler RK, Bartram CR, Burwinkel B: Copy number variant in the candidate tumor suppressor gene MTUS1 and familial breast cancer risk. Carcinogenesis 2007, 28:1442-1445.

doi:10.1186/bcr3678

Cite this article as: Lee et al:: Breast cancer risk assessment using genetic variants and risk factors in a Singapore Chinese population. Breast Cancer Research 2014 16:R64.

\section{Submit your next manuscript to BioMed Central and take full advantage of:}

- Convenient online submission

- Thorough peer review

- No space constraints or color figure charges

- Immediate publication on acceptance

- Inclusion in PubMed, CAS, Scopus and Google Scholar

- Research which is freely available for redistribution 